\title{
Santos Brasil Effects Of The Privatization Of The Port Of Santos Container Terminal (TECON1) - An Administrative Study Under The Logistics And Operations Approach
}

Angela Dannemann (E-mail: adannemann@institutomultiplicar.org.br), IBMEC-RJ Business School Gilberto Braga (E-mail: gbraga@ibmecrj.br), IBMEC-RJ Business School

Professor Luiz Antonio Lopes Ph.D (E-mail: laslopes@uol.com.br), IBMEC-RJ Business School

\begin{abstract}
The objective is to investigate the results of the privatization of the Port of Santos container terminal (TECON1), under an administrative view focused on logistics and operational aspects. An analysis of TECON1's operational conditions which motivated the privatization, its performance prior to privatization, the conditions of the lease contract signed and the changes occurred following the change in management. The report presents the main managerial introductions made to TECON1, such as the development of the computer system CTIS (Container Terminal Information System) and the recovery of wharves services, which finally culminated in cost reduction of standard container moves.
\end{abstract}

\subsection{Introduction}

$B$

razil's slow but continuous evolution from an economy characteristically agricultural to one currently diversified and industrialized has placed the country, in the last decade, between the $8^{\text {th }}$ and $10^{\text {th }}$ world economy measured by its GNP. To date, besides being one of the largest Soya bean, orange and coffee producers and exporters, Brazil is also an important player in the steel, automobile and airplane markets, goods with a higher added value, whose productivity and competition compare to those produced and exported by highly developed economies.

For a country with such a huge coastal extension, approximately 5,750 miles, the existence of modern and efficient harbors, equipped with installations capable of fulfilling a growing trade demand and ready to face an extremely developed competition, is an essential component of foreign trade. Brazil started this transformation after breaking open its trade barriers in 1990 and after congress' approval of the Harbor Modernization Law in 1993, when investment in harbor infrastructure was enhanced towards providing them with efficiency and competitiveness and to better insert the country into the international trade market.

New models of industrial organization with the merging of companies into global conglomerates and the application of modern technologies such as "Just in Time" generated demand for ever smaller transportation times to avoid stock build-up. In order to adapt to these new models, break bulk was the cargo type that underwent the greatest amount of change. Time spent in harbor operations had to be drastically reduced, especially in cargo loading and unloading, and the safety of all operations had to be enhanced, in order to lessen cargo damage and loss.

Readers with comments or questions are encouraged to contact the authors via email.

Containers as a solution for break bulk transportation became commonplace by the 1980's. This rectangu- 
lar steel box, with a standard length of either 20' or 40' (respectively with 17 metric ton capacity and 22 metric ton capacity), conveying all kinds of break bulk: car parts, steel spools, ore in bulk, mattresses or orange juice; proved itself an effective handling and transportation method. It has drastically reduced inefficiencies within the transportation network and the value-added chain. Small ships conveying all kinds of cargo in their hold, that took several days and employed large numbers of unqualified labor to load and unload, are being traded for large full container carriers. The latter are handled in specialized and highly automated wharves (Container Terminals - TECON), which employ labor specifically trained to operate state of the art equipment.

The existence of modern and efficient container terminals, adjusted to this new model of unified cargo, comprising special areas (open space for container handling and stacking) and modern handling equipment (ship to shore cranes, transtainers and high capacity cranes) is essential to promote and develop Brazil's foreign trade and to insert the country into the most relevant international trade routes.

After due reflection of the small role performed by TECON1, when compared to the huge development potential of container transportation in Brazil, complementary studies are recommended from the starting point of this research, for a deeper analysis and follow-up of this essential service.

\subsection{Environment}

The modernization of harbors in Brazil is initiated only after congress approval of Law No. 8630, dated February 25, 1993, and signed by President Itamar Franco. Decision making on this matter was urgent due to several reasons, some of which have been stated below:

- $\quad$ Decaying image of Brazilian harbors originated by:

$\checkmark \quad$ Expensive operation

$\checkmark \quad$ Obsolete equipment

$\checkmark \quad$ High corruption

- $\quad$ Strong social and economic pressure towards harbor modernization

- $\quad$ Lack of proper investment after the mid 1980's

- $\quad$ Privatization considered best solution for harbor operation modernization

- $\quad$ State owned Harbor Companies (Companhias Docas) were facing an unbalanced financial situation, with a growing deficit, due to loss of income and incompatible personnel related expense

- Urgent demand that harbors become regional development centers and rational links of the logistic chain

In 1995, CODESP (Companhia Docas do Estado de São Paulo), the state company in charge of Santos Harbor, underwent several restructuring processes. All of them were based on a study named "Santos 2000 Project: Preparing the Harbor for the XXI Century", which resulted in CODESP becoming a Port Authority. Its new functions were limited to coordination and inspection of the harbor activity, rather than harbor operation (Rodrigues et al., 2000). This study proposed, among other things, the switch of all harbor operation to private enterprise. Several lease areas where designated, which added to a total of 4,5 million square meters (1,112 acres) out of the 7,7 million (1,903 acres) that comprised Santos Harbor as a whole.

The end of 2000 had leased 2 million square meters (494 acres) of the area under Port Authority management for operation by private companies.

On December 17, 1997 TECON1 (Container Terminal 1), one of Santos harbor container terminals belonging to CODESP is leased to private enterprise, by means of a public bidding process, for a period of 25 years, to be postponed for 25 more. SANTOS-BRASIL S.A., becomes the successful bidder of the privatization auction for the operation of TECON1. It is created as a specific purpose society to operate the terminal, established by the following private companies: Opportunity Leste S.A., Multiterminais Alfandegados do Brasil Ltda., 525 Participações S.A., Caixa de Previdência dos Funcionários do Banco do Brasil - Previ e Fundação Sistel de Seguridade Social. Initial operation occurred through an operational management agreement with the German company HHLA (Hamburger Hafen und Lagerhaus AG) and its affiliate company, HPC (Hamburg Port Consultancy GmbH), both with ex- 
tensive experience in harbor operation and with main offices located in the city of Hamburg, Germany.

\subsection{Objective}

The goal of this research study was to inquire into the results of the privatization of TECON1, one of Santos' Harbor container terminals located in the town of Guarujá, which originally occurred by the end of 1997. The subject is analyzed through a logistics and operations approach, and has tried to determine how relevant the switch from state to private management has been to changes in TECON1's performance.

Evolution of the terminal's productivity has been studied to find an answer to the following questions:

1) Has there been improvement in harbor activity with TECON1's privatization?

2) Can improvements possibly encountered in the answer to the first question be assigned to a new model of company logistic management?

\subsection{Methodology}

All theoretical references adopted in this research have been acquired during the Operations and Logistics classes, part of the Masters in Business Administration of IBMEC - RJ Business School and attended by the authors (Bowersox et al, 2001). They were applied at all stages of the study, as follows: (i) surveys of terminal data before and after privatization; (ii) interviews with TECON1 technical staff; (iii) visit to TECON1's site; and (iv) survey of comparative data.

Essential indicators of harbor activity researched, for month or year intervals, are the following: (i) container physical moves; (ii) ship waiting time on the roads; (iii) ship load and unload times; (iv) container handling and empty container depot; and (v) income and expense in US dollars.

From the starting point of the indicator survey the study has attempted to correlate the logistics and operations procedures before and after TECON1's privatization. The goal was to establish and measure harbor activity productivity rates. The result that was expected with this research was to confirm that the current terminal performance could be attributed to a new management model that has introduced new logistics concepts.

\subsection{Description and Analysis}

\subsection{TECON1 Characteristics and Initial Conditions}

TECON1 is an area located on the left side of the Santos estuary, more specifically at a place called "Conceiçãozinha", where, since the 1980 's, the only specialized container terminal of Santos harbor was being operated. With a total area of approximately 484,000 square meters (120 acres), 366,000 (90 acres) already operational and 118,000 (30 acres) to be expanded in the future, it comprises a mooring wharf 510 meters long, expandable to 760 $\mathrm{m}$. Standard depth of quays is 13.5 meters.

Included in the original site were administrative buildings, workshops, warehouses, storage yards, power substation and access gates. Also, as part of the mandatory equipment list, the terminal possessed 5 ship to shore cranes, 5 transtainers on wheels and rails, 5 reach stackers, 10 tractors, 10 tows and stock for spare parts of this equipment (all equipment previously mentioned are imported, except the last two).

By the end of 1999, information provided by the Ministry of Transportation (GEIPOT, 1999) allowed comparison of substructures of all main container terminals of Santos Harbor, seen below on Table 1: 
Table 1: Container Terminal Comparison - Santos Harbor 1999

\begin{tabular}{|l|c|c|c|}
\hline Item & TECON1 & Libra & Cosipa \\
\hline Maritime Access & Left Bank & Right Bank & Off Port Limits \\
\hline Railway Access & Good & Bad & Excellent \\
\hline Highway Access & Good & Bad & Excellent \\
\hline Area $\left(\mathrm{m}^{2}\right)$ & 366,000 & 170,000 & 90,000 \\
\hline Wharf Length $(\mathrm{m})$ & 510 & 1,110 & 342 \\
\hline Depth $(\mathrm{m})$ & 13 & N/A & 12 \\
\hline Number of Quays & 2 & 5 & N/A \\
\hline Ship to Shore Cranes & 5 & 6 & N/A \\
\hline
\end{tabular}

N/A - data not available

Source: GEIPOT

The greatest advantage of TECON1, when compared to local competition, is its large back area, which allows for better container handling and storage. This large back area is a competitive advantage with its competitors, since no other has a comparable area. Another important competitive advantage at TECON1 are two railway terminals located within its back area, belonging to FEPASA and MRS Logística, connecting cargo to the larger area of São Paulo state and beyond. Notwithstanding the still very low usage of railways in Brazil, less than $1 \%$ of all cargo transportation, there is no denying the strategic relevance of this logistic link in a not very distant future.

This is a summary of conditions encountered at TECON1 previous to privatization:

- $\quad$ TECHNOLOGY - Operations controlled manually

- $\quad$ EQUIPMENT - Loading / unloading equipment either non-functional or in a precarious condition

- $\quad$ WHARF - Mooring capacity for 2 midsize vessels

- $\quad$ LABOR - Huge number of single workers (temporary workers untrained and with selection processes controlled by unions)

- $\quad$ STORAGE - Storage yard unused

- $\quad$ IRRATIONALITY - Cargo commonly transferred to intermediate depots at the backyard area of the harbor, with no set safety procedures for this move. The creation of 2 unnecessary container moves was uncalled for due to the availability of terminal storage areas, being cause for logistic inefficiencies and cost raise.

The situation encountered right after the privatization process demanded immediate investment, already predicted in the winning proposal. The schedule predicted a 240 million reais investment until 2010, divided in two stages: 143 million between 1998 and 2003 and 97 million from 2004 to 2010. Presented below are the details of the two stages of the investment plan:

$1^{\text {st }}$ Stage:

- Wharf and storage yard recovery

- Wharf length expansion to 760 meters (adding $250 \mathrm{~m}$ to the current 510), for additional mooring quays, enhancing operation to 3 simultaneous vessels

- $\quad$ Reform of existing equipment (removal of ship to shore cranes 1 and 2, non-recoverable and obsolete and reform of ship to shore cranes 3,4,5 and 6) purchase of new equipment, adapted to larger vessels (reach stackers, transtainers, tow trucks and stackers)

- $\quad$ Purchase of an information system in order to automate terminal operation

$2^{\text {nd }}$ Stage: 
- $\quad$ Purchase of two new ship to shore cranes and spare parts

- $\quad$ Further storage yard recovery

The predicted investment would allow the terminal to operate 600,000 containers/year, with a $30 \mathrm{MPH}$ (moves per hour) average productivity rate.

SANTOS BRASIL's challenge was to organize a new company, with modern management and control views in order to attain international standards. New management would be providing criteria and parameters to allow proper market evaluation of company procedures and financial statements. These were not unrealistic goals, if TECON1's following characteristics are considered:

a) $\quad 100 \%$ foreign trade operations

b) All agreements under a US dollar base

c) Internal controls regulated both by local and international codes and rules

d) Competition with other local container terminals, either within the same harbor or neighboring harbors, for the same market area (southeastern and south geographical regions and part of the central west region, all part of the larger markets and higher income areas of Brazil)

\subsection{Competition}

The growing relevance of foreign trade as Brazil's entrance gate into global economy places a spotlight over the harbor system, as an important market sector for investment. Container terminals become crucial components of this system, in order to face the global trend towards efficiency that retires old break bulk ships and promotes full container carriers, ever larger and more specialized, such as the PANAMAX and POST PANAMAX types. In order to follow this direction, Brazilian harbors had already started to build container terminals before the harbor Modernization Law, and currently offer terminals better equipped and more competitive than ever.

SANTOS BRASIL's main competitors are currently those located within Santos harbor itself, listed below, and with their characteristics shown at Table 2 which follows:

\footnotetext{
- $\quad$ Libra terminal 37

- $\quad$ Libra terminal 34-35

- Cosipa

- $\quad$ Tecondi
}

Besides Santos harbor, there are several other alternative container terminals, also located within the southsoutheast region, which may become important competitors on the long run. Among others, they are the container terminals of harbors located in Rio de Janeiro, Sepetiba and Paranaguá (the first two in the state of Rio de Janeiro and the latter in the state of Paraná). However, none of them are as close to São Paulo and the adjacent areas under its market influence (states of Minas Gerais, Mato Grosso do Sul, Mato Grosso, Goiás and Paraná) who concentrate $55 \%$ of Brazil's GNP and $49 \%$ of the country's production. In addition to that, they are far from reaching SANTOS BRASIL's operational capacity. See Table 4 in the Appendix to have a full view of container terminal throughput around Brazil between 1997 and 2001.

\subsection{Santos Brasil - Challenges and Operational Conditions}

The services rendered by a container terminal comprehend the loading and unloading of containers and warehousing services (cargo storage and logistical services, which include cargo separation, consolidation and refrigeration, and cargo transfer to diverse modals). Parallel to all these services are the customs procedures, done according to Brazilian Customs regulations. 
Table 2 - Container Terminal Comparison - Santos Harbor 1999

\begin{tabular}{|c|c|c|c|c|c|}
\hline Item & TECON1 & Terminal 37 & Terminal 34-35 & COSIPA & TECONDI \\
\hline Maritime Access & Excellent & \multicolumn{2}{|c|}{ Excellent } & Average & Excellent \\
\hline Railway Access & Good & \multicolumn{2}{|c|}{$\mathrm{Bad}$} & Excellent & Average \\
\hline Highway Access & Good & \multicolumn{2}{|c|}{$\mathrm{Bad}$} & Excellent & Average \\
\hline Depth & Good & \multicolumn{2}{|c|}{ Good } & Good & Good \\
\hline Number of Quays & Good & \multicolumn{2}{|c|}{ Excellent } & $\mathrm{Bad}$ & Good \\
\hline Ship to Shore Cranes & Good & \multicolumn{2}{|c|}{ Excellent } & Very Bad & Very Bad \\
\hline Back Storage Area & Excellent & \multicolumn{2}{|c|}{ Bad } & $\mathrm{Bad}$ & Average \\
\hline Operator & Santos Brasil & Libra & Libra & Libra & Denver C.Floriano \\
\hline Depth (m) & 13 & 12 & 12 & 10 & 12 \\
\hline Number of Quays & 2 & 2 & 3 & 1 & 3 \\
\hline Wharf Length (m) & 510 & 400 & 170 & 300 & 700 \\
\hline Terminal Area $\left(\mathrm{m}^{2}\right)$ & 366,000 & 69,000 & 100,000 & 90,000 & 170,000 \\
\hline Railway Network & Ferroban / MRS & Ferroban / MRS & Ferroban / MRS & Ferroban / MRS & Ferroban / MRS \\
\hline \begin{tabular}{|l|} 
Productivity \\
\end{tabular} & $22,2 \mathrm{cont} / \mathrm{h}$ & 20,8 cont $/ \mathrm{h}$ & N/A & N/A & N/A \\
\hline Quay Use Rate & $55 \%$ & $55 \%$ & N/A & N/A & $2^{\text {nd }}$ semester 2000 \\
\hline Concession Period (years) & $25+25$ & $20+20$ & N/A & N/A & N/A \\
\hline
\end{tabular}

N/A - data not available

Source: Mercer Management Consulting

The following graph shows the market share of these terminals for 2001:

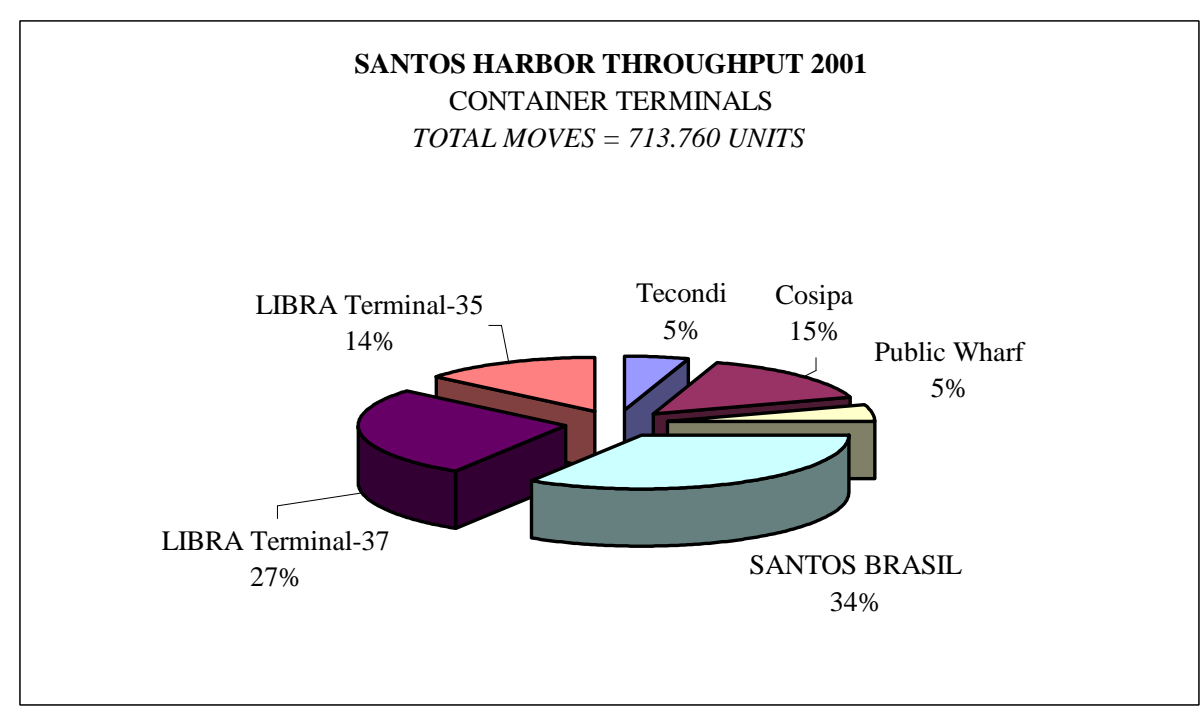


Below is a simple scheme that describes operations inside a container terminal:

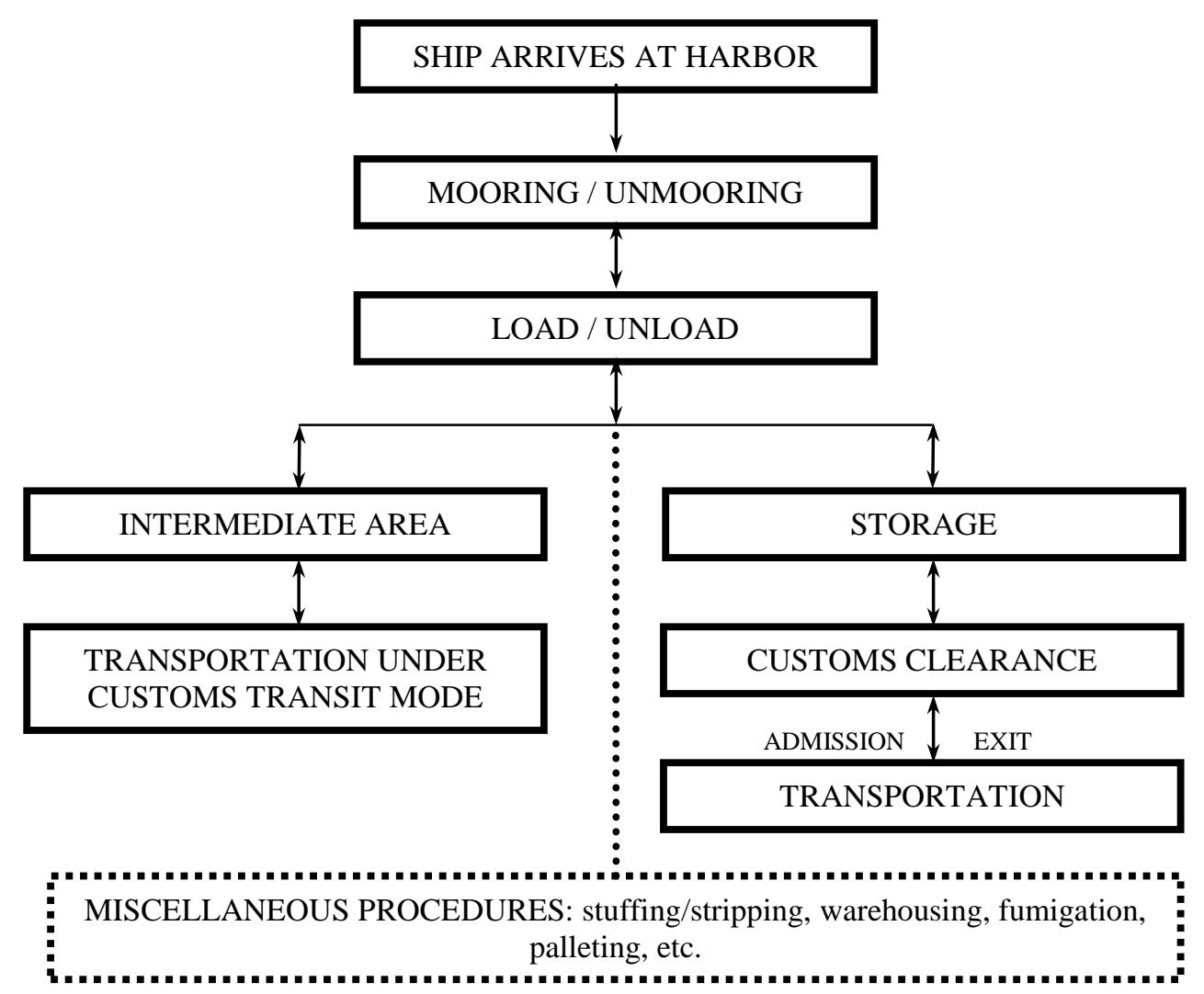

When analyzing SANTOS BRASIL's operation through its billing procedures, one may label their incomes into two types:

- Wharf Operations: which represent $75 \%$ of total income and comprehend the container load/unload procedures of 52 ships per month belonging to 9 shipowners that are the current clients (seen above from the first box up to and including the "Load/Unload" box)

- $\quad$ Container storage, warehousing, stuffing / stripping, which represent $25 \%$ of total terminal income (seen above by all boxes below the "Load/Unload" box)

The variety of possible procedures associated to container terminal operation and the need to fulfill customer specific requests, imposes that all operations be controlled by an information system with a high degree of specialization and customization. Besides this, modern container terminals are operated by fully automated equipment that load and unload cargo, as well as handle, store and transfer cargo to other modals.

\section{Control System}

According to what has been observed, situation prior to privatization was precarious in operations as much as with control tools. There were two possible alternatives for SANTOS BRASIL's management. Either to develop a specific system which would take a very long time, or to purchase a standard package where alterations could be made in regard to terminal peculiarities and regulation specifics. Since time was essential, the second alternative was the one employed. 
Thus was initiated the operational agreement with HHLA/HPC that started to technically restructure the terminal and to adapt, develop and install the CTIS (Container Terminal Information System) information system.

CTIS characteristics:

- Integrated system for control of terminal operations based on company logistics

- Technology know-how from HHLA/HPC, and joint development through a 3 year agreement, that brought together HPC and SANTOS BRASIL personnel in the process of adaptation

- $\quad$ System running over UNIX, developed through UNIFACE programming language and ORACLE database

The final product was an entirely automated management tool, customized to customers' demands and to Brazil's constantly mutating regulations. CTIS has many working interfaces: with the financial control systems used at SANTOS BRASIL (developed by Microsiga); with the billing system and with several external systems such as SISCOMEX (foreign trade governmental agency), shipowners systems and the Brazilian Customs. In addition to that it manages the differences between foreign forms and the Brazilian customs standard form, in order to avoid documentation problems.

CTIS controls all terminal operations, including:

a) ship booking

b) load/unload schedules

c) order of stuffing/stripping procedures

d) container refrigeration control

e) storage planning

f) admission/exit gates

g) labor shifts

h) equipment selection/scheduling

CTIS is a highly complex system. Among other services, it produces a full mapping of container location inside the ship, separating by size and weight, appropriate to the incoming ship's characteristics and determining the ship's preferable mooring side. A job previously performed manually by CODESP personnel that generated a high percentage of error and took long periods of time to finish.

The interfaces created with other systems have admitted faster customs clearance, where all document inspection can be done electronically using bar codes. This has greatly reduced the waiting times at gates and transfers for the diverse modals. Lastly, interface with the billing system has become an essential part of the company's performance evaluation, either under a technical or financial view.

These are some distinctive functions of CTIS, presented here in more detail:

a) Booking Function

$\checkmark \quad$ Shipowner sends ship schedule directly to CTIS via EDI (Electronic Data Interchange)

$\checkmark \quad$ Shipowner sends most recent cargo load map, when leaving the last port before Santos

$\checkmark \quad$ Full logistic integration for cargo load alterations in order to fulfill unpredicted or unexpected orders/commissions - partnership between SANTOS BRASIL and shipowners to comply with last minute requests

$\checkmark \quad$ Document generation for customs and other inspections

b) Gates Function (8 intelligent gates)

$\checkmark \quad$ Super Scanner - that inspects and verifies without opening container

$\checkmark \quad$ Input / Output on CTIS by bar code optical identification (only system with this characteristic, that 


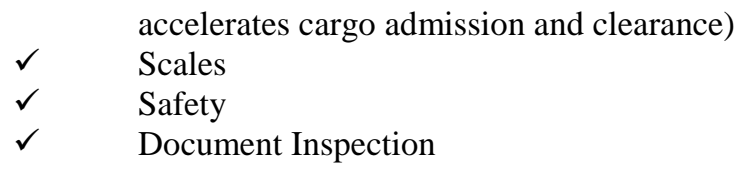

To make it simple, CTIS is responsible to determine the optimal location of containers in the storage area, as well as the order that they will be loaded/unloaded, in order to reduce the number of moves for every loading and unloading of ships - an important indicator of terminal productivity.

\section{Other Important Components}

One of the main hindrances to the evolution of Brazilian harbors into global service level is the capital/labor relation. Strong unions, bred without any control that usually overextend their labor protection activities have been creating severe trouble and laying a heavy burden to Brazil's harbor operations. The measure adopted by the Modernization Law of 1993 in order to reduce this excessive power was the creation of OGMO (Office of Labor Management). One of OGMO's roles was to concentrate under the category of "single labor" all harbor workers dismissed from the State Harbor Companies, whilst their coming to be Port Authorities. Single labor should then be further assigned to harbor operators either as "linked labor" (workers employed by port operators) or "single labor" (workers temporarily assigned to a port operator per operation).

Unfortunately this process is still under way, and in older harbors such as Santos, unions still hold their power in determining the number of workers to be employed for every operation, as well as which individual or group will be employed.

This burden can be demonstrated below, in Table 3, where labor employed at container terminals is presented for different harbors.

Table 3 - Average Labor Employed

\begin{tabular}{|l|c|c|}
\hline Harbor & Country & Labor Employed \\
\hline Buenos Aires & Argentina & 14 a 19 \\
\hline Callao & Peru & 20 a 25 \\
\hline Valparaíso & Chile & 20 a 25 \\
\hline Antwerp & Belgium & 7 a 8 \\
\hline Barcelona & Spain & 14 \\
\hline Santos & Brazil & 50 \\
\hline
\end{tabular}

Source: SANTOS BRASIL

Here are some of the challenges yet to be faced by all parts involved, summarized below:

- $\quad$ Law determines that workers on board ship have to be hired with OGMO, cannot be part of the port operator staff

- $\quad$ Port operators are not part of single labor selection processes. Single labor is appointed by the union (union appoints approximately 150 workers per ship, when operations are almost totally automated)

- $\quad$ Single labor are not trained as the linked labor

- $\quad$ Although single labor is needed for terminal operations, during the 2001 strike, SANTOS BRASIL alone managed all port operations of 20 ships for 21 days without any single labor involved.

- SANTOS BRASIL estimates show that the annual cost of single labor amounts to 25 million reais, an excess of 20 million reais per year (its estimates also show that no more than 5 million reais should be spent per year with single labor) 
Another important component of logistic efficiency is the product delivery cycle, i.e. the number of links in the supply chain and the total amount of time spent between them. Fulfilling expected times is one of the most important jobs of the service provider, in order to avoid flaws in their customers operations. This particular type of inefficiency became a habit at Santos harbor. It made use of an excessive number of TRA (terminals located at the area of the backyard or neighboring areas and under customs regulations) before harbor modernization. These TRA would store containers and break bulk that could not be kept at the harbor area, due to lack of space or to cultural habit. Currently, in most cases, they are just an additional link to the logistics chain, adding unneeded storage cost to customers bills.

Based on data provided by SANTOS BRASIL, this phenomenon can be demonstrated by the following:

- $\quad$ Container retention rate at SANTOS BRASIL (number of containers stored in the terminal expecting their final destiny per total containers handled) corresponds to $30 \%$

- $10 \%$ of all containers proceed to EADI (terminals adjacent to production centers and under customs regulations, located around Brazil) - where product/merchandise is stored right next to production or distribution centers, fulfilling the most modern logistics concepts

- $60 \%$ still stop by the TRA's, adding unneeded logistic links to the chain, due to cultural habit and prior harbor inefficiencies

- Distance by land between the left and the right banks of Santos harbor is $45 \mathrm{~km}$, even though it is only 500 $\mathrm{m}$ across by water. The abovementioned added links also submit the cargo to safety hazards and delays due to excessive traffic on the right bank of the estuary (right bank roads pass through Santos urban perimeter). This unnecessary $45 \mathrm{~km}$ "ride" in fact is charged as a $90 \mathrm{~km}$ freight, because billing is done over both ways (taking of the cargo and return of the empty truck). This means that besides higher safety hazards due to excessive container handling ( 2 times more), there are also added freight and insurance costs.

Lack of knowledge on foreign trade regulations is an additional complication pointed out by SANTOS BRASIL. Small import/export companies, have little or no knowledge of logistics and legal regulations. A large number of these companies trust their import/export procedures to third parties, who are not entirely committed to procure the least expensive ways for their clients, and, instead, try to financially benefit their intermediate logistic link. This, in part, is an explanation to the TRA phenomenon, which further raises the final cost for the importer/exporter.

The final outcome of all this logistic irrationality is what has been called by SANTOS BRASIL's CEO, Wady Jasmim - logistic culture inertia (the natural resistance to change).

\section{Performance}

Nowadays, SANTOS BRASIL, taken under an operational and cost-based view, may be compared to its similar sized international pairs such as Sidney, Australia and Miami, USA.

Some practical examples of what has been stated above follow:

- $\quad$ Caterpillar (CAT) -client that imports spare parts with cargo dispatch happening in up to 6 hours

- Volkswagen - exports with a lead time of 0.38 days under the "blue line" system (prior customs clearance)

- $\quad$ SANTOS BRASIL is the only container terminal authorized by customs to operate with the blue line system

- $\quad$ Only harbor in Brazil to receive ISO 14.001, certified by SGS (environmental management)

- ISO 9.001 of total quality management to be ratified by SGS (date predicted for certification September, 2002)

However, SANTOS BRASIL's performance is impaired when compared to similar European and American terminals. The average size of ships faring along Brazilian harbors have a negative influence on 
performance, compared to those operating at international harbors such as Hamburg and Singapore (see Appendix, Table 4).

Average consignment is the same. That is, if the ships operating at the best international harbors would come to SANTOS BRASIL, its productivity could double. This can be explained by the fact that ships operating at "first class" harbors are gearless vessels (no crane on deck), that allow for higher ship to shore crane efficiency (ship to shore cranes sweep the whole deck because there are no obstacles). At Brazil, half of all cargo ships operated at SANTOS BRASIL still belong to the old type that has its own deck cranes and equipment. In fact, for many harbors along the Brazilian coast, this equipment is still requested, because of delay in modernization of terminals, what further hampers performance.

By august 2002 the wharf expansion was finished, rendering a new wharf length of 760 meters. Ratification of the job by the Port Authority (CODESP) is expected by September. The new wharf length will allow the simultaneous mooring of 2 large size ships type POST PANAMAX or 3 midsize. It will also allow for the creation of new operational lines for the POST PANAMAX vessels, providing SANTOS BRASIL with an additional advantage.

Some data has to be pointed out relative to performance in comparison to the previous state management by CODESP: (see Appendix for the complete group of indicators)

- $\quad$ Terminal operation lead-time reduction - time for cargo loading/discharging reduced from 5 days (4 days waiting times on the roads and 1 for the operation) to 1 day (1.5 hours waiting times on the roads and 1 for the operation).

- $\quad$ Productivity gains - raise in number of container moves per hour (MPH) from 11 to $40 \mathrm{MPH}$, sometimes reaching $70 \mathrm{MPH}$.

- $\quad$ Price reduction - the 4 year term has produced a container move cost reduction from an initial US\$ 500600 to US\$180-200

- $\quad$ Record of efficient operation - average of 36 moves per hour versus 11 moves at past critical moments.

- $\quad$ Large scale operation - only terminal capable of operating large size ships, PANAMAX and POST PANAMAX that are capable of carrying 4,500 containers or more (older vessels can only carry 400 to 1,200 containers).

As could be demonstrated above, the high lead-time and low productivity prior to TECON1 privatization were a good reason for the high operational cost - a negative cause/effect relation.

Performance improved due to the application of advanced technology and competent operation by the new port operator. Pressured by the demands of an entrepreneurial activity, unlike the goals of a public organ, the port operator must seek the return of their shareholders investment. To attain this goal SANTOS BRASIL has established modern control methods and pre-established criteria for its evaluation parameters.

\subsection{Conclusion}

There has been an undeniable improvement of harbor activity with TECON1's privatization. Performance data presented beforehand and the most relevant performance indicators can confirm this statement. The MPH indicator (see Appendix) - moves per hour - had a 170\% growth when comparing the best index before privatization (13) to the last index for $2001(35,5)$. If we take into consideration the waiting times on the roads, it is currently 12 times smaller than before the privatization, 1.7 hours versus 22 hours. Further, when considering cargo-handling prices, they have been reduced to $2 / 3$ of what they used to be. These indicators alone are enough to answer our research question.

We may also assert, with no doubt, that the improvements are due to the new model of company logistics, introduced after privatization, more specifically due to the full-fledged process automation that was initiated at the terminal, right after the privatization. The newly expanded wharf, 760 meters long, able to moor 2 POST PANAMAX vessels will allow further improvements, for SANTOS BRASIL is the only terminal at Santos harbor capable 
of handling great amounts of containers at a time with its huge back storage yard. The growth in the number of routes operated by gearless vessels will further improve SANTOS BRASIL's position with a scale gain - modern equipment and a large storage yard will allow for a higher productivity in a short period of time. Finally, stimulation of growth in the number of gearless vessels' routes by SANTOS BRASIL and other modern Brazilian terminals, and appropriate parallel structural investment, will have a chain reaction effect in improving other harbors along the Brazilian and southern Atlantic coast and raising income for all involved.

In spite of SANTOS BRASIL's excellent performance there are still several challenges to be faced in order to heighten the terminal's operational output and add value to all supply chain components. The crash between modern management techniques and obsolete procedures still places a burden on Brazilian harbor operations. Some procedures worth mentioning were uncontrolled capital/labor relations, excessive regulatory environment, lack of foreign trade knowledge and no history of associative groups to promote collective interests towards more modern procedures.

Also relevant, but in a lesser way, was some imprecision during the privatization process of Santos' harbor areas. Most important was the predicted amount of container moves for TECON1, today confirmed as way too optimistic, which have created frustration as to the investment capabilities and to return on investment.

Brazil Federal Government's pledge towards fully applying the original intentions of the Harbor Modernization Law, specially its labor feature, with a consistent policy towards the reduction of union power, reinforcement of the OGMO, and better aligned judicial decisions at the Labor Courts, would be of great service towards reducing what is commonly known as "Brazil Cost" at the harbor sector.

Greater efforts by the Development, Industry and Commerce Ministry, towards better guidance of the small and medium sized Brazilian entrepreneur at foreign trade procedures. Other by the Transportation Ministry and the Treasury Ministry, towards the development of more efficient harbor and customs procedures, would all contribute to the improvement of harbor operation, especially that of container terminals.

According to SANTOS BRASIL's CEO, Wady Jasmim, there are four variables that affect foreign trade cost: exchange rates, logistics, duties and credit. These variables, all under regulatory government influence, may be taken together or separately to tax or dispense foreign trade operations, specially the logistic variable.

Nevertheless, it is certain that the installation and use of CTIS and all reform that has been processed around the terminal have created the smallest logistic path between the gate and the ship deck. CTIS is adding value to the supply chain, reducing cost to all its members and, consequently, allowing for more and better logistic tradeoffs. The constant improvement of productivity indicators proves this statement and is reinforced by SANTOS BRASIL's latest financial statement. Even if container operation around the Santos harbor area is growing slower, when compared to growth in other harbors of southern Brazil (see Appendix - Table 5).

SANTOS BRASIL has introduced into Brazilian harbor operation a new logistics efficiency concept. Prior to its introducing of additional land services to stored containers, terminals were evaluated by its vertical efficiency, i.e. only by the ship load/unload times. These services have now created the new measurement of horizontal logistic efficiency, where services that add value to the business as a whole, raise income and reduce cost transaction can now be measured and compared.

The current scenario of Brazilian economy, by unanimity of opinion by renowned economists, places the spotlight on foreign trade as a means to enhance capital influx. In such a scenario the improvement of harbor activity becomes a most relevant component. The so-called mini-tax reform recently published (Temporary Measure no. 66/2002) that intends to eliminate tax overburden on trade is essential. Much has been done lately to reduce tax burden on foreign trade. The Kandir Law and the privatization of harbors itself are clear demonstration of this trend in the past decade or so. But there is still the need to go beyond the regulatory aspect of this matter to further deepen the operational efficiency theme. Privatized harbor operation, with the good results shown by SANTOS BRASIL's example, can have a major role and a positive contribution towards the country's economic growth. 


\section{Bibliography}

1. BOWERSOX, Donald J. et CLOSS, David J. Logística Empresarial: o Processo de Integração da Cadeia de Suprimento. Translation: Adalberto Ferreira das Neves. São Paulo: Atlas, 2001. Original Title: Logistical Management: the Integrated Supply Chain Process.

2. BRASIL. Law no. 8.630 of February 25, 1993. Instructs about the legal regime for exploration of organized harbors and harbor installations and other instructions. Diário Oficial da União, Brasília, Feb. 26, 1993.

3. GEIPOT - EMPRESA BRASILEIRA DE PLANEJAMENTO DE TRANSPORTES, MINISTÉRIO DOS TRANSPORTES. A Reforma Portuária Brasileira. Joint report prepared with the World Bank. Brasília: June, 1999.

4. JASMIM, Wady et al. Interview with SANTOS BRASIL S.A. Staff. Santos, 2002. Questions and answers recorded in cassette tape and extensive visit of the container terminal.

5. Overall Container Handling in Brazilian Harbors. Brasília, Ministry of Transportation, 2001. Presents worksheet comparing brazilian container terminal throughput up to the year 2001. Available at: www.transportes.gov.br/STA/Dportos/estatistica/Anu.../II__MovGeralConteineres.html Access on April 20, 2002.

6. PINTO, Andre T. Interview with INTEGRAL Ltda. Staff. Rio de Janeiro, 2002. Questions and answers registered in writing and extensive visit of their container terminal.

7. RODRIGUES, José et VAZ, José P. Porto de Santos: uma Década de Transformações. São Paulo: UNISANTA. 2001.

8. $\quad$ SANTOS BRASIL. Project Finance. São Paulo, SP, 2000.

\section{Appendix}

Table 4 - Top 10 Container Ports Comparison for 2001 (adds Brazil Total)

$\begin{array}{ll} & \text { TEU } \\ \text { Hong Kong (China) } & 17,900,000 \\ \text { Singapore } & 15,520,000 \\ \text { Pusan (Korea) } & 7,900,000 \\ \text { Kaohsiung (Taiwan) } & 7,540,000 \\ \text { Shanghai (China) } & 6,334,000 \\ \text { Rotterdam (Netherlands) } & 6,129,000 \\ \text { Los Angeles (USA) } & 5,184,000 \\ \text { Shenzen (China) } & 5,040,000 \\ \text { Hamburg (Germany) } & 4,700,000 \\ \text { Long Beach (USA) } & 4,463,000 \\ \text { Brazil Total } & 2,992,206\end{array}$


SANTOS BRASIL INDICATORS

\begin{tabular}{l|cccccrrrr} 
INDICATORS & $\mathbf{1 9 9 3}$ & $\mathbf{1 9 9 4}$ & $\mathbf{1 1 9 5}$ & $\mathbf{1 9 9 6}$ & $\mathbf{1 9 9 7}$ & $\mathbf{1 9 9 8}$ & $\mathbf{1 9 9 9}$ & $\mathbf{2 0 0 0}$ & $\mathbf{2 0 0 1}$ \\
\hline MOVES PER HOUR (MPH) & $\mathrm{N} / \mathrm{A}$ & 11,8 & 11,0 & 13,0 & 11,0 & 26,4 & 30,2 & 36,7 & 35,5 \\
WAITING TIME & $\mathrm{N} / \mathrm{A}$ & $\mathrm{N} / \mathrm{A}$ & $\mathrm{N} / \mathrm{A}$ & 29,0 & 22,0 & 3,4 & 1,4 & 1,6 & 1,7 \\
MARKET SHARE & 48,5 & 44,3 & 34,6 & 34,4 & 36,1 & 39,3 & 37,5 & 39,5 & 36,6
\end{tabular}
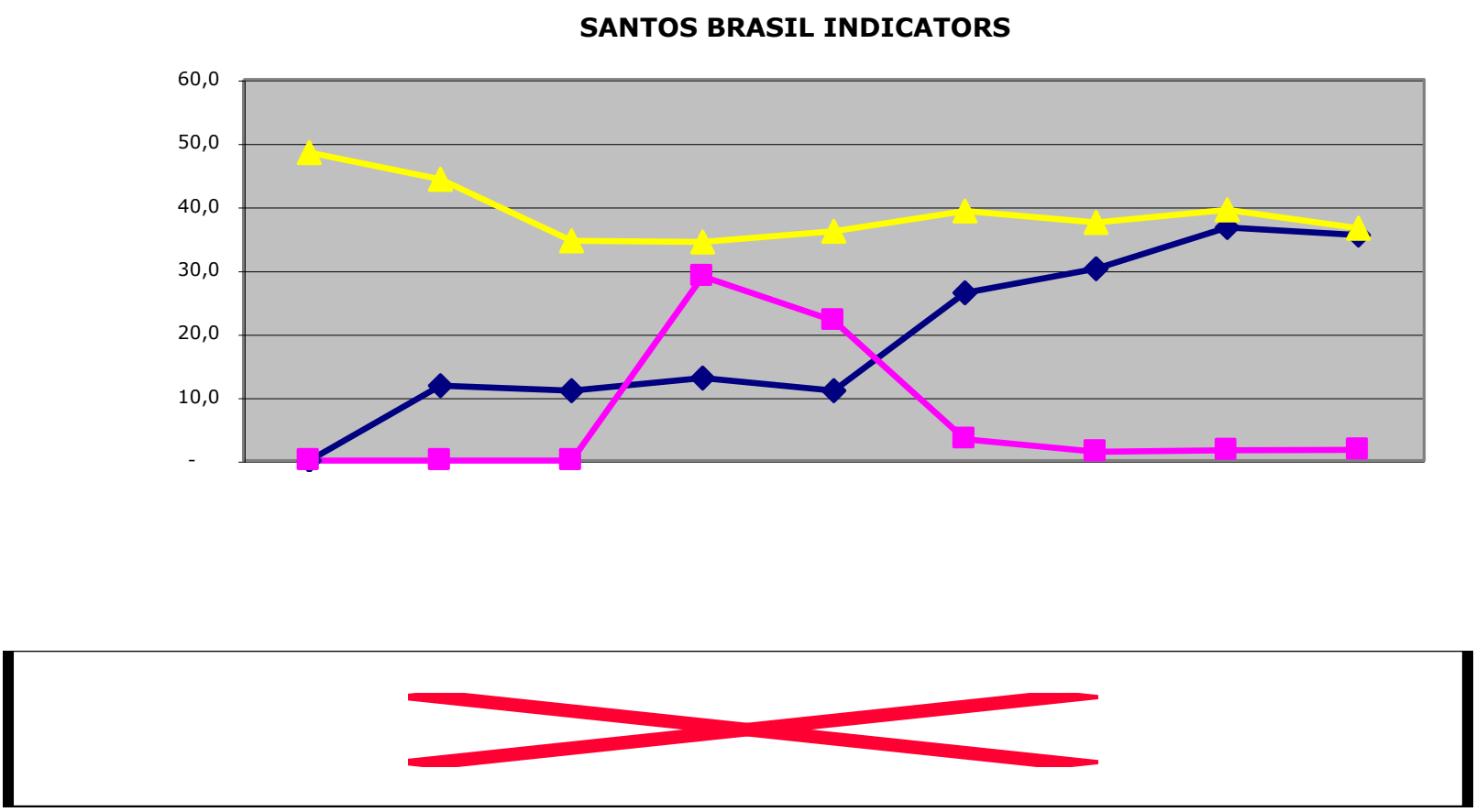

THROUGHPUT COMPARISON

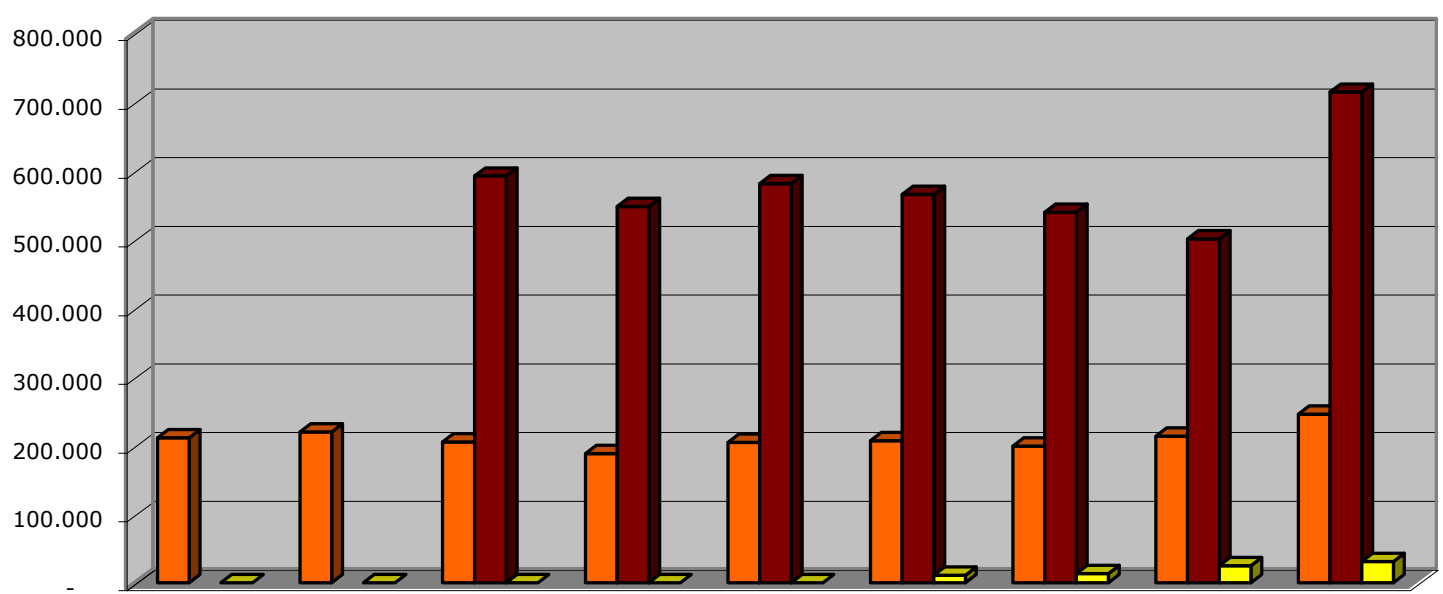




\begin{tabular}{l|rrrr} 
FINANCIAL INDICATORS & \multicolumn{1}{|c}{1998} & \multicolumn{1}{c}{$\mathbf{1 9 9 9}$} & \multicolumn{1}{c}{$\mathbf{2 0 0 0}$} & \multicolumn{1}{c}{$\mathbf{2 0 0 1}$} \\
\hline NET INCOME & 91.296 & 106.100 & 102.924 & 136.860 \\
EBITDA & 16.442 & 28.328 & 21.640 & 47.486 \\
EBITDA MARGIN & 18,0 & 26,7 & 21,0 & 34,7
\end{tabular}

FINANCIAL INDICATORS

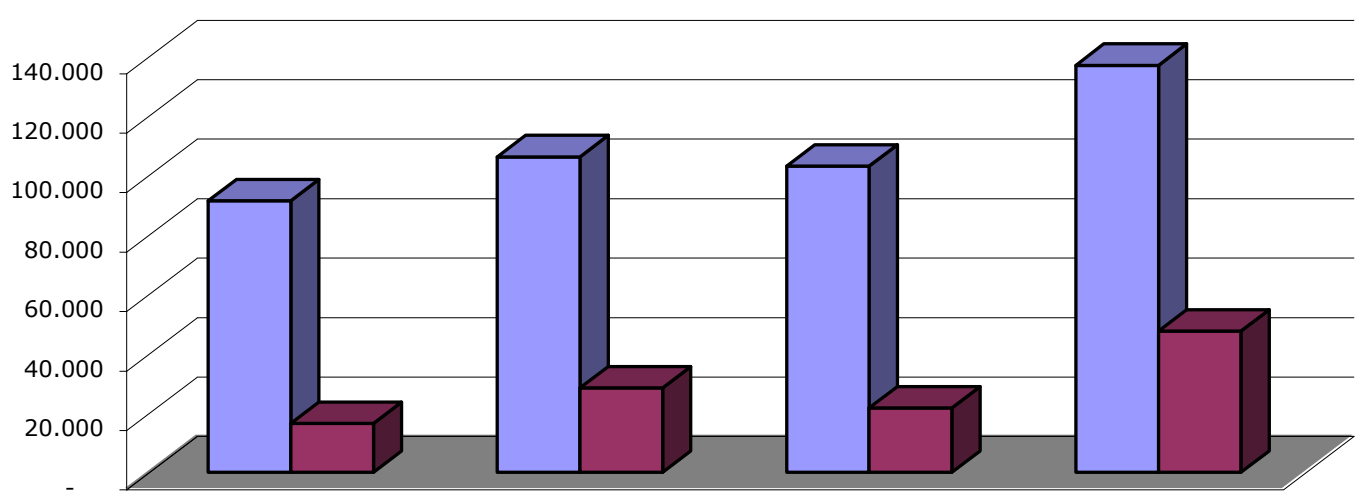

Table 5 - Brazilian Container Terminal Comparison (moves in TEU)

\begin{tabular}{|l|r|r|r|r|r|}
\hline PORTO & \multicolumn{1}{|c|}{$\mathbf{1 9 9 7}$} & $\mathbf{1 9 9 8}$ & $\mathbf{1 9 9 9}$ & $\mathbf{2 0 0 0}$ & \multicolumn{1}{c|}{$\mathbf{2 0 0 1}$} \\
\hline SANTOS-SP & 829,486 & 799,476 & 774,959 & 950,969 & $1,054,969$ \\
\hline RIO GRANDE-RS & 194,963 & 224,577 & 261,929 & 317,718 & 361,046 \\
\hline PARANAGUÁ-PR & 139,141 & 161,569 & 194,939 & 252,678 & 291,649 \\
\hline RIO DE JANEIRO-RJ & 202,763 & 198,197 & 204,289 & 220,332 & 248,779 \\
\hline ITAJAÍ-SC & 118,822 & 129,563 & 136,062 & 176,813 & 243,552 \\
\hline S. FRANC. SUL-SC & 95,394 & 116,707 & 151,111 & 168,355 & 167,294 \\
\hline SALVADOR-BA & 52,496 & 51,375 & 79,116 & 95,451 & 106,712 \\
\hline ESPIRITO SANTO-ES & 62,472 & 107,373 & 114,588 & 91,757 & 114,803 \\
\hline MANAUS-AM & 60,783 & 44,078 & 48,553 & 86,944 & 106,617 \\
\hline FORTALEZA-CE & 42,148 & 50,163 & 51,626 & 69,424 & 80,281 \\
\hline SUAPE-PE & 30,642 & 48,953 & 39,142 & 63,561 & 73,358 \\
\hline BELÉM-PA & 26,982 & 29,843 & 47,283 & 49,044 & 48,147 \\
\hline RECIFE-PE & 23,784 & 19,675 & 26,526 & 27,249 & 47,096 \\
\hline NATAL-RN & 281 & 613 & 2,914 & 5,226 & 2,588 \\
\hline PORTO ALEGRE-RS & 2,208 & 4,759 & 3,368 & 4,054 & 8,756 \\
\hline SEPETIBA-RJ & $\mathrm{N} / \mathrm{A}$ & $\mathrm{N} / \mathrm{A}$ & $\mathrm{N} / \mathrm{A}$ & 3,681 & 25,402 \\
\hline MACEIO-AL & 3,968 & 3,325 & 3,920 & 3,316 & 7,956 \\
\hline CABEDELO-PB & 10,496 & 6,404 & 4,224 & 1,211 & 822 \\
\hline ILHÉUS-BA & 2,784 & 6,384 & 1,105 & $\mathrm{~N} / \mathrm{A}$ & 2,379 \\
\hline TOTAL & $\mathbf{1 , 8 9 9 , 6 1 3}$ & $\mathbf{2 , 0 0 3 , 0 3 4}$ & $\mathbf{2 , 1 4 5 , 6 5 4}$ & $\mathbf{2 , 5 8 7 , 7 8 3}$ & $\mathbf{2 , 9 9 2 , 2 0 6}$ \\
\hline
\end{tabular}

Source: Ministry of Transportation 
Notes 